\title{
Usefulness of the C-Reactive Protein in Predicting the Need for Antibiotics Among Febrile Inpatients with Sickle Cell Disease ${ }^{\mathrm{S}}$
}

\author{
Jeffrey Gershel ${ }^{*}, 1$, Robyn Kreiner ${ }^{2}$, Gila Spitzer ${ }^{3}$, Adam Sterman ${ }^{2}$, Emily K. Slotkin ${ }^{3}$ and Kenneth Rivlin ${ }^{1}$ \\ ${ }^{I}$ Department of Pediatrics, Jacobi Medical Center, Bronx, New York, USA \\ ${ }^{2}$ Department of Pediatrics, Children's Hospital at Montefiore, Bronx, New York, USA \\ ${ }^{3}$ Department of Pediatrics, Memorial Sloan Kettering Cancer Center, New York, New York, USA
}

\begin{abstract}
Objective: To determine whether the C-reactive protein (CRP) can help identify which febrile patients with sickle cell disease $(\mathrm{SCD})$ require antibiotic therapy.

Patients and Methods: We performed a chart review of patients with SCD (including S-S, S-C, and S-Thal) admitted to the hospital with fever [temperature $>38.3^{\circ} \mathrm{C}<2$ years of age; $>38.9^{\circ} \mathrm{C} \geq 2$ years of age] over a thirty-month period (July 2009 - December 2011). Data extracted included temperature, age, high sensitivity CRP value, chest $x$-ray and culture results, and the underlying cause of fever, categorized as bacterial (antibiotics necessary) or non-bacterial (antibiotics not necessary). The Mann-Whitney U-test was then used to compare the median CRP levels of patients requiring antibiotics versus those whose illnesses did not require antibiotic treatment.

Results: Fifty-four febrile patients with SCD were admitted to the hospital. Nineteen had final diagnoses that required antibiotic treatment and their median CRPs were significantly higher than the thirty-five who had diagnoses that did not meet the requirements for antibiotic treatment $(100.9 \mathrm{mg} / \mathrm{L}$ vs $17.3 \mathrm{mg} / \mathrm{L}, \mathrm{p}<.001)$. All patients who needed antibiotics had a CRP $>39 \mathrm{mg} / \mathrm{L}$.

Conclusion: The current data indicate that among febrile patients with SCD, the CRP may help differentiate bacterial infections which require antibiotic treatment from other diseases for which antibiotics are not necessary. Our data suggests that there may be a level of CRP below which a bacterial etiology is unlikely.
\end{abstract}

Keywords: C-reactive protein, fever, sickle cell disease.

\section{INTRODUCTION}

Patients with sickle cell disease (SCD) often require hospitalization for a number of complications, including vasoocclusive crisis (VOC), acute chest syndrome (ACS)/pneumonia, aplastic crisis, splenic sequestration, bacteremia, and osteomyelitis. These conditions may have similar clinical presentations, including fever, bone pain, and/or respiratory distress. Therefore, early in the clinical course of an acute illness, it may be difficult to distinguish among these entities and choose the most appropriate initial therapy.

It is well known that patients with SCD are at an increased risk for overwhelming systemic bacterial infections with S. pneumoniae, H. influenzae, N. meningitidis, and Salmonellae [1, 2]. Current guidelines suggest treating with broad spectrum antibiotics any child with SCD who presents with a fever $>38.3-38.9^{\circ} \mathrm{C}\left(>101-102^{\circ} \mathrm{F}\right)[3,4]$ At the same

*Address correspondence to this author at the Department of Pediatrics, Jacobi Medical Center, Bronx, New York, USA; Tel: 718918 5304;

Fax: 718918 5007; E-mail: Jeffrey.gershel@nbhn.net

${ }^{\S}$ Presented in part at the Pediatric Academic Societies Meeting, Denver, May 1, 2011 and the Pediatric Hospital Medicine Meeting, Cincinnati, July 19, 2012. time, there is a growing concern about antibiotic overuse, so that many institutions have instituted antibiotic stewardship programs [5].

At present, there are no easily obtained, and consistently reliable, laboratory examinations that distinguish between patients who have VOC or a non-bacterial illness (do not require antibiotics) from those with bacteremia, sepsis, ACS/pneumonia, osteomyelitis, or other diagnoses for which antibiotics are necessary. Inflammatory markers that have been studied include the erythrocyte sedimentation rate (ESR), which is typically low in patients with SCD as the cells do not form rouleaux [6] The ESR may increase during both painful crises and infections, but it does not reliably differentiate between the two [7]. West et al. [8] showed that there are significant increases in white blood cells, absolute neutrophil, and absolute band counts when comparing SCD patients with and without bacteremia. However, there were too few episodes of bacteremia to determine reliable cutoffs. In contrast, secretory phospholipase A2 is an accurate test for identifying present or incipient ACS in young patients who were present to the emergency department with VOC, although it is not in widespread use [9]. Procalcitonin is a sensitive inflammatory marker, however data is insufficient to conclude that an elevation reliably identifies children with SCD who have bacterial infections [10]. 
A readily available marker of systemic inflammation is the C-reactive protein (CRP), named for its ability to form a precipitate with polysaccharide $\mathrm{C}$ of Streptococcus pneumoniae. It is an exquisitely sensitive acute phase reactant that has gained wide acceptance as an indicator of systemic inflammation [11]. There is recent evidence that the CRP is elevated in VOC [12]. although there are limited data regarding the reliability of the CRP for discriminating between VOC and other critical illnesses in patients with SCD and fever. Therefore, a more comprehensive understanding of the CRP in SCD may potentially aid in addressing the clinical dilemma of distinguishing VOC from other entities requiring antibiotics.

\section{METHODS}

We performed a chart review of patients with SCD (including S-S, S-C, and S-Thal) who were admitted to the Jacobi Medical Center with fever over a thirty-month period (July 1, 2009 through December 31, 2011). Data extracted included temperature, age, high sensitivity CRP value, culture and chest-ray results (if obtained), and the underlying cause of fever, categorized as bacterial (antibiotics necessary) and non-bacterial (antibiotics not necessary). The study protocol was approved by the IRB of both the Albert Einstein College of Medicine and the New York City Health and Hospitals Corporation.

\section{Subjects}

Inclusion criteria: Febrile patients 3 months to 24 years of age with SCD (S-S, S-C, S-Thal) were eligible if a CRP and, at a minimum a blood culture, were obtained as part of the emergency department work-up prior to admission to the inpatient unit.

Exclusion criteria: Patients were excluded if they had received antibiotics during the previous five days (except for prophylactic penicillin) and/or a blood transfusion during the previous three months.

\section{Fever}

Fever was defined as a temperature $>38.3^{\circ} \mathrm{C}$ (patients $<2$ years of age) or a temperature $>38.9^{\circ} \mathrm{C}$ (patients $\geq 2$ years of age).

\section{Diagnoses Definitions}

Bacterial infections: Patients were classified as having a bacterial illness if a bacterial culture (blood, urine, stool) was positive for a known pathogen. Diagnoses included ACS/ pneumonia, bacteremia, sepsis, osteomyelitis, pyelonephritis, bacterial enteritis, and cellulitis. The diagnosis of ACS/ pneumonia required the presence of a new infiltrate on a chest $\mathrm{x}$-ray that was interpreted by a pediatric radiologist. The diagnosis of osteomeyelitis was confirmed by MRI results.

Non-bacterial illnesses: Patients were classified as having a non-bacterial illness if all bacterial cultures (blood, urine, stool), and a chest x-ray, if obtained, were negative. Diagnoses included VOC, viral syndrome, asthma/bronchiolitis, splenic sequestration, aplastic crisis, and gastroenteritis.

\section{CRP}

High sensitivity CRP was measured using commercially available immunoturbidimetric methods and the 67-Integra machine. Reagents containing latex particles coated with mouse or rabbit anti-CRP antibodies were mixed with the patient's sample. The subsequent precipitate was analyzed for decreased intensity of light. The reference range for patients $>2$ months of age was $0.1-2.8 \mathrm{mg} / \mathrm{L}$.

\section{Data Analysis}

We compared the median CRP values between febrile inpatients that truly required antibiotics for diagnoses of bacteremia, sepsis, ACS/pneumonia, osteomyelitis, and urinary tract infection versus febrile inpatients who ordinarily would not require antibiotic therapy for their diagnoses (VOC, aplastic crisis, splenic sequestration, and viral illnesses). Anderson-Darling tests revealed that while the median CRPs of the antibiotics required patients had a normal distribution $(p<0.1795)$, the antibiotics not required cohort did not have a normal distribution $(\mathrm{p}<.0005)$. Therefore, the Mann-Whitney U-test was used to compare median CRP levels between these groups.

\section{RESULTS}

There were a total of fifty-four febrile episodes among forty-five different patients. Nine patients were admitted twice; two required antibiotics during both admissions, four required antibiotics during one admission, and three did not require antibiotics during either admission. As shown in Table 1, there was no significant difference in age or gender distribution between the two groups. However, nineteen inpatients had final diagnoses that required antibiotic treatment and their median CRPs were significantly higher than the thirty-five inpatients who did not need antibiotics $[\mathrm{CRP}=100.9 \mathrm{mg} / \mathrm{L}(\mathrm{IQR} 82.9)$ vs $\mathrm{CRP}=17.3 \mathrm{mg} / \mathrm{L}$, $\mathrm{p}<0.001$ (IQR 47.7)].

As shown in the box plot (Fig. 1), every patient who required antibiotics had a CRP level $>39 \mathrm{mg} / \mathrm{L}$.

\section{DISCUSSION}

The CRP has been studied as a diagnostic tool in a variety of illnesses. In the pediatric population, CRP has been utilized in diseases such as Kawasaki disease [13], asthma [14], appendicitis [15], and neonatal sepsis [16]. Recently, an elevation of the CRP has been noted in children with SCD during episodes of vasoocclusive crisis [17].

Distinguishing VOC from other SCD complications, including those requiring antibiotics, remains a clinical dilemma. Our findings suggest that CRP levels may provide additional guidance when the etiology of a patient's pain or fever is ambiguous. Specifically, these data indicate that the CRP may aid in distinguishing bacterial infections (antibiotics necessary) from presumed viral infections (no antibiotics needed) in febrile patients. Our results suggest that for febrile patients with SCD, there may a level of CRP below which a bacterial etiology is unlikely. Further prospective study with larger numbers of patients is therefore necessary to confirm whether the CRP is a reliable predictor of a bacterial illness. 
Table 1. Comparison of patients who did and did not require antibiotics.

\begin{tabular}{|c|c|c|}
\hline & $\begin{array}{l}\text { Antibiotics } \\
\text { Necessary }\end{array}$ & $\begin{array}{c}\text { Antibiotics Not } \\
\text { Necessary }\end{array}$ \\
\hline Number of Patients & 19 & 35 \\
\hline Age Mean (months) $\pm \mathrm{SD}$ & $116.8 \pm 77.5$ & $78.1 \pm 74.1^{1}$ \\
\hline Gender (male/female) & $8 / 11$ & $23 / 11^{1}$ \\
\hline CRP Median (IQR) & $100.9(51.9,140.8)$ & $17.3(6.3,54.0)^{2}$ \\
\hline CRP Range & $39.2-204.8$ & $0.7-142.3$ \\
\hline \multicolumn{3}{|l|}{ Hemoglobin } \\
\hline S-S & 11 & 29 \\
\hline S-C & 5 & 5 \\
\hline S-Thal & 3 & 1 \\
\hline \multicolumn{3}{|l|}{ Final Diagnoses } \\
\hline ACS/pneumonia & 9 & \\
\hline Bacteremia/sepsis & 4 & \\
\hline Osteomyelitis & 2 & \\
\hline Pyelonephritis & 2 & \\
\hline Bacterial enteritis & 1 & \\
\hline Cellulitis & 1 & \\
\hline VOC & & 18 \\
\hline Viral syndrome & & 9 \\
\hline Asthma/bronchiolitis & & 3 \\
\hline Splenic sequestration & & 3 \\
\hline Aplastic crisis & & 1 \\
\hline Gastroenteritis & & 1 \\
\hline
\end{tabular}

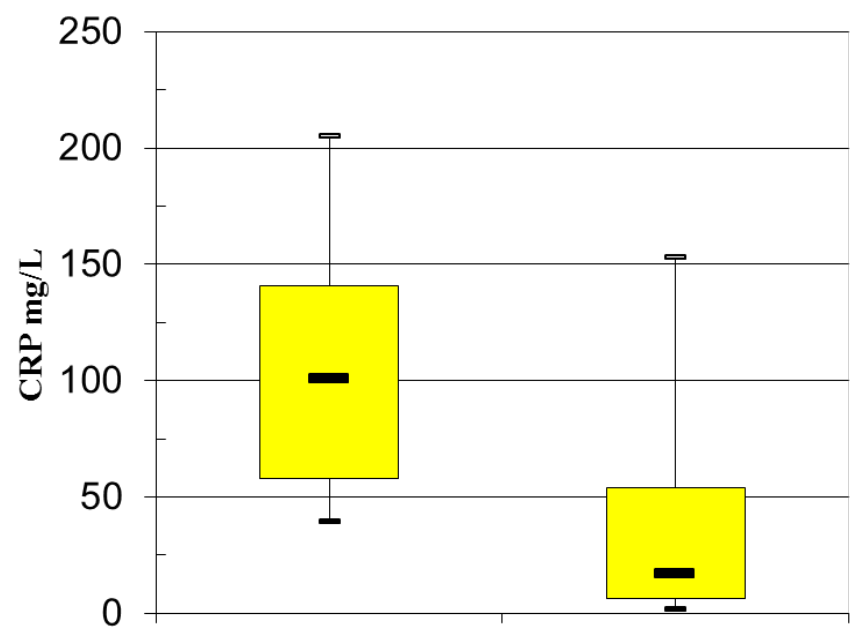

Antibiotics Needed Antibiotics Not Needed

Fig. (1). Comparison of CRP levels between patients who did and did not require antibiotics.

\section{LIMITATIONS}

The present study has a number of important limitations. 1) The data was collected retrospectively and may therefore reflect errors or omissions in the electronic records. 2) We report on a relatively small number of patients, so it is possible that a few outlier results may affect the findings and conclusions. 3) We had too few patients to stratify the data based on type of hemoglobinopathy, bacterial organism identified, and final discharge diagnosis.

\section{ABBREVIATIONS}

$\begin{array}{lll}\text { ACS } & = & \text { Acute chest syndrome } \\ \text { CRP } & = & \text { C-reactive protein } \\ \text { SCD } & = & \text { Sickle cell disease } \\ \text { VOC } & = & \text { Vasoocclusive crisis }\end{array}$

\section{CONFLICT OF INTEREST}

The authors confirm that this article content has no conflict of interest.

\section{ACKNOWLEDGEMENTS}

Declared none.

\section{REFERENCES}

[1] Ramakrishnan M, Moïsi JC, Klugman KP, et al. Increased risk of invasive bacterial infections in African people with sickle-cell disease: a systematic review and meta-analysis. Lancet Infect Dis 2010; 10: 329-37.

[2] Battersby AJ, Knox-Macaulay HH, Carrol ED. Susceptibility to invasive bacterial infections in children with sickle cell disease. Pediatr Blood Cancer 2010; 55: 401-6.

[3] Weinblatt M. Sickle cell disease. In: Crain EF, Gershel JC, Eds. Clinical manual of emergency pediatrics. $5^{\text {th }}$ ed. Cambridge, UK: Cambridge University Press 2010; pp. 354-9.

[4] Thompson ED Jr, Rivlin K. Sickle cell disease. In: Rauch D, Gershel JC, Eds. Caring for the hospitalized child: a handbook of inpatient pediatrics. Elk Grove. California: American Academy of Pediatrics 2013; pp. 267-75.

[5] Newland JG, Gerber JS, Weissman SJ, et al. Prevalence and characteristics of antimicrobial stewardship programs at freestanding children's hospitals in the United States. Infect Control Hosp Epidemiol 2014; 35: 265-71.

[6] Bunting H. Sedimentation rates of sickled and non-sickled cells from patients with sickle cell anemia. Am J Med Sci 1939; 198: 191-3.

[7] Stuart J, Stone PC, Akinola NO, Gallimore JR, Pepys MB. Monitoring the acute phase response to vaso-occlusive crisis in sickle cell disease. J Clin Pathol 1994; 47: 166-9.

[8] West DC, Andrada E, Azari R, Rangaswami AA, Kuppermann N. Predictors of bacteremia in febrile children with sickle cell disease. J Pediatr Hematol Oncol 2002; 24: 279-83.

[9] Ballas SK, Files B, Luchtman-Jones L, et al. Secretory phospholipase A2 levels in patients with sickle cell disease and acute chest syndrome. Hemoglobin 2006; 30: 165-70.

[10] Unal S, Arslankoylu AE, Kuyucu N, et al. Procalcitonin is more useful than C-reactive protein in differentiation of fever in patients with sickle cell disease. J Pediatr Hematol Oncol 2012; 34: 85-9.

[11] Pepys MB, Hirschfield GM. C-reactive protein: a critical update. J Clin Invest 2003; 111: 1805-12.

[12] Akinlade KS, Atere AD, Olaniyi JA, Rahamon SK, Adewale CO. Serum copeptin and cortisol do not accurately predict sickle cell anaemia vaso-occlusive crisis as C-reactive protein. PLoS One 2013; 8:e77913.

[13] Newburger JW, Takahashi M, Gerber MA, et al. Committee on Rheumatic Fever, Endocarditis, and Kawasaki Disease, Council on Cardiovascular Disease in the Young, American Heart Association. Diagnosis, treatment, and long-term management of Kawasaki disease: a statement for health professionals from the Committee on Rheumatic Fever, Endocarditis, and Kawasaki Disease, Council 
on Cardiovascular Disease in the Young, American Heart Association. Pediatrics 2004; 114: 1708-33.

[14] Deraz TE, Kamel TB, El-Kerdany TA, El-Ghazoly HM. Highsensitivity $\mathrm{C}$ reactive protein as a biomarker for grading of childhood asthma in relation to clinical classification, induced sputum cellularity, and spirometry. Pediatr Pulmonol 2012; 47: $220-5$.

Received: December 24, 2014

Revised: March 30, 2015

Kwan KY, Nager AL. Diagnosing pediatric appendicitis: usefulness of laboratory markers. Am J Emerg Med 2010; 28: 1009-15.

[16] Hofer N, Zacharias E, Müller W, Resch B. An update on the use of C-reactive protein in early-onset neonatal sepsis: current insights and new tasks. Neonatology 2012; 102: 25-36.

[17] Mohammed FA, Mahdi N, Sater MA, Al-Ola K, Almawi WY. The relation of C-reactive protein to vasoocclusive crisis in children with sickle cell disease. Blood Cells Mol Dis 2010; 45: 293-6.

(C) Gershel et al.; Licensee Bentham Open.

This is an open access article licensed under the terms of the Creative Commons Attribution Non-Commercial License (http://creativecommons.org/licenses/by-nc/ 3.0/) which permits unrestricted, non-commercial use, distribution and reproduction in any medium, provided the work is properly cited. 